НАУКОВИЙ ВІСНИК

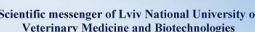

(1)

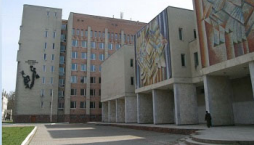

RIIS: VETERINARY SCIENC

Том 22 № 100

2020
Науковий вісник Дьвівського національного університету ветеринарної медицини та біотехнологій імені С.3. Гжицького. Серія: Ветеринарні науки

\section{Scientific Messenger of Lviv National University of Veterinary Medicine and Biotechnologies. Series: Veterinary sciences}

UDC 547.497.6

\title{
The mechanism of action and modified synthesis of hydroxyurea
}

\author{
O. G. Demchuk, M. R. Hrytsyna, L. O. Kobryn, M. B. Kalytovska, B. V. Gutyj \\ Stepan Gzhytskyi National University of Veterinary Medicine and Biotechnologies Lviv, Ukraine
}

Article info

Received 02.10.2020 Received in revised form 03.11 .2020

Accepted 04.11.2020

Stepan Gzhytskyi National University of Veterinary Medicine and Biotechnologies Lviv, Pekarska Str., 50, Lviv, 79010, Ukraine. Tel.: +38-097-255-17-98 E-mail:hrytsynamr@gmail.com
Demchuk, O. G., Hrytsyna, M. R., Kobryn, L. O., Kalytovska, M. B., \& Gutyj, B. V. (2020). The mechanism of action and modified synthesis of hydroxyurea. Scientific Messenger of Lviv National University of Veterinary Medicine and Biotechnologies. Series: Veterinary sciences, 22(100), 6065. doi: $10.32718 /$ nvlvet10011

Searching of new drugs with antimitotic characteristics which can be used for decreasing of cancer cells dividing is the important issue of nowadays. One of such substances there is a hydroxyurea (HU) that is known as mitotical poison, because of characteristic to block a cellular cycle and as the specific inhibitor of DNA synthesis. It blocks the transition of cells from GI - in S-phase. HU is a cytostatic agent with antineoplastic activity and presents great clinical efficiency in the treatment of sickle cell disease. $H U$ and its derivatives exhibit versatile biological activities. $H U$ is currently used in the treatment of various neoplastic and non-neoplastic diseases such as cancer, sickle cell anemia and HIV.Currently anticancer drugs are available that significantly reduce the mortality rates for some cancers (e.g. leukemia and testicular and ovarian cancer), and give longer overall patient survival times. In order to drug belongs to the pharmacotherapeutic group - antineoplastic agents and widely used for myelogenous leukemia, essential thrombocythemia treatment, our research was concerning the literature review on the ways and mechanisms of action of $H U$ in living organisms. The ways and mechanisms of HU action in living organisms, research of antiviral and antimicrobial action of $H U$, the mechanism of $H U$ influence at the cellular level and in antitumor and anticancer therapy have been studied. Under studying of radioprotector properties of hydroxyurea was established, that its efficiency is estimated by the values FCD (Factor of change of dose) within the limits of 1.2-1.4 - (to the peas 1.4 and corn - 1.3). A factor of change of dose is a relation of effective dose at the irradiation of organism with a radioprotector to the effective dose that predetermines the same radio-biology effect in control without a radioprotector. It was established that compounds with sulfurhydryl bonding possess the most radioprotective properties. It is considered that they have strong reduction properties and can be used as spin trapping of free radicals, shutting them out before binding with macromoleculas occurs, in particular to DNA. In order to obtain a sufficient amount of the drug hydroxyurea for analytical and pharmacological research, a modified method of it synthesis has been developed and proposed. The optimized synthesis conditions include conducting the experiment at lower temperatures $-15{ }^{\circ} \mathrm{C}$ (wise $-10{ }^{\circ} \mathrm{C}$ lit.), neutralization of the reaction mixture with concentrated $50 \%$ sulfuric acid (wise dilute sulfuric acid, lit.); providing concentrated solution by reducing the total amount of water in the reaction $300 \mathrm{ml}$ (wise $500 \mathrm{ml}$ ); evaporation and the filtration at room temperature by air flow (wise evaporation in vacuum at $40{ }^{\circ} \mathrm{C}$, lit.); replacement of the solvent for extraction with butanol (wise alcohol, lit.). Such conditions provided complete dissolution of urethane after $1 \mathrm{~h}$ and allow to receive the hydroxyurea pure enough, without further recrystallization. The target product was obtained with a higher yield (up to $91 \%$ ) and achieved simplicity and one-step method. The less toxic and cost-effective starting reagents were also used to reduce the cost of the synthesis process.

Key words: hydroxyurea, hydroxycarbamide, colour reactions, qualitative analyses, quality control.

\section{Механізм дії та модифікований синтез гідроксисечовини}

\author{
О. Г. Демчук, М. Р. Грицина, Л. О. Кобрин, М. Б. Калитовська, Б. В. Гутий
}

Львівський національний університет ветеринарної медицини та біотехнологій імені С. 3. Гљсицького, м. Львів, Україна 
Пошук нових препаратів з антимітотичними характеристиками, які можна використовувати для зменшення поділу ракових клітин, є важливим питанням сьогодення. Однією з таких речовин є гідроксисечовина, яка відома як мітотична отрута, через властивість блокувати клітинний иикл. Як специфічний інгібітор синтезу DNA вона блокує перехід клітин з G1 - в S-фазу. Гідроксисечовина є цитостатичним засобом, щуо володіє протипухлинною активністю, і має велику клінічну ефективність при лікуванні серповидно-клітинної хвороби. Гідроксисечовина та ї̈ похідні виявляють різнобічну біологічну активність. В даний час гідроксисечовина використовується для лікування різних новоутворень та протипухлинних захворювань, таких як рак, серповидно-клітинна анемія та ВІЛ. Так як допоміжний препарат значно знижує рівень смертності при деяких інших видах раку (лейкемії, раку чоловічих і жіночих статевих органів) , тим самим збільиуючи життя пацієнтів. 3 огляду на те, щуо препарат належить до фармакотерапевтичної групи - антинеопластичні засоби, має широке застосовання при мієлолейкозі есенціальній тромбоцитемії, наші дослідження розпочалися з огляду літературних джерел про шляхи та механізми дії НU в живих організмах. Опрацьовано літературні джерела щзодо иляхів та механізмів дї̈ НU в живих організмах, дослідження противірусної та антимікробної дії НU, механізму впливу НU на клітинному рівні та у протипухлинній та протираковій терапії. Завдяки тому, щуо НU має здатність пригнічувати поділ клітин за рахунок блокування вилки реплікації DNA, ией препарат використовується як антинеопластичний засіб в гематологї та для лікування онкологічних захворювань. При вивченні радіопротекторних властивостей гідроксисечовини було встановлено, шео ї̈ ефективність оцінюється за значеннями FCD (фактор зміни дози) в межах 1,2-1,4- (до гороху 1,4 та кукурудзи - 1,3). Фактор зміни дози - ие відношення ефективної дози при опроміненні організму радіопротектором до ефективної дози, яка зумовлює той самий радіобіологічний ефект при контролі без радіопротектора. Встановлено, щзо сполуки із сульфідрильним зв'язком мають найбільш радіозахисні властивості. Вважається, щуо вони мають сильні відновлювальні властивості і можуть бути використані як спін-захоплення вільних радикалів, вимкнення їх перед тим, як відбувається зв'язування з макромолекулами, зокрема з DNA. 3 метою отримання достатньої кількості препарату гідроксисечовини для аналітичних та фармакологічних досліджень розроблено та запропоновано модифікований спосіб його синтезу. До оптимізованих умов синтезу можна віднести проведення експерименту при нижчих температурах $-15{ }^{\circ} \mathrm{C}$ ( $-10{ }^{\circ} \mathrm{C}$ літ.), нейтралізація реакиійної суміші концентрованою $50 \%$ сірчаною кислотою (а не розбавленою, літ.); забезпечення концентрованих умов за рахунок зменшення загальної кількості води в реакції 300 мл (500 мл, літ.); випаровуванням фільтрату при кімнатній температурі потоком повітря (випаровування в вакуумі при $40{ }^{\circ} \mathrm{C}$, літ); заміна розчинника для екстракцією на бутанол (спирт, літ.). Такі умови забезпечили повне розчинення уретану вже через 1 год, щуо дозволило отримати иільовий продукт вищим виходом (до 91 \%) у чистому вигляді, який практично не вимагає перекристалізації. У синтезі досягнуто простоту і одностадійність методу та використані мени токсичні і економічно вигідні вихідні реагенти.

Ключові слова: гідроксисечовина, гідроксикарбамід, кольорові реакиії, якісний аналіз, контроль якості.

\section{Ветуп}

Пошук шляхів синтезу якісних і ефективних дженериків, відомих брендових лікарських препаратів вітчизняного виробництва, дозволяе істотно знизити витрати на їх закупівлю, особливо це стосується препаратів протипухлинної дії. Серед сучасних протилейкемічних засобів особливого значення набуває малотоксичний засіб гідроксисечовина (Hydroxyurea далі $\mathrm{HU})$, який випускається під назвами: гідроксисечовина, гідроксикарбамід, гідракс, гідрея, онкокарбід, оксимід, оксисечовина та давно застосовується в країнах Європи. На ринку України продається препарат "Гідроксисечовина Медак" (Hydroxyurea Medac) (Люм'єр Фарма) Hydroxycarbamidum. Довгий час цей препарат входив до списку державного замовлення Міністерства охорони здоров'я для онкохворих, зокрема раку крові. За зовнішнім виглядом це капсули 500 мг, № 100 з діючою речовиною є гідроксикарбамід (hydroxycarbamid); 1 капсула містить 500 мг гідроксикарбаміду (гідроксисечовини).

HU є діючою речовиною препарату Гідроксикарбамід (Hydroxycarbamide далі НC), який вперше був затверджений у 1967 році для медичного використання у Сполучених Штатах Управлінням з санітарного нагляду за якістю харчових продуктів та медикаментів, США (FDA) та знаходиться у списку Всесвітньої організації охорони здоров'я.

3 огляду на те, що препарат належить до фармакотерапевтичної групи - антинеопластичні засоби, має широке застосовання при мієлолейкозі есенціальній тромбоцитемії, наші дослідження розпочалися з огляду літературних джерел про шляхи та механізми дії HU в живих організмах.
Механізм впливу НU на клітинному рівні. Механізм впливу HU на різні стадії клітинного циклу було встановлено ще у 60-х роках минулого століття на прикладі культивованих клітин китайського хом'яка. Досліджено вплив HU на клітини, що синтезували DNA (S-фаза) та клітини, що перебували у активній фазі росту, яка передує синтезу DNA $\left(\mathrm{G}_{1}\right)$. Відмічено порушення нормального синтезу клітин у обидвох випадках. Клітини, що знаходилися у фазі активного росту $\left(\mathrm{G}_{2}\right)$ після синтезу DNA виживали і розвивалися лише до початку наступного періоду синтезу DNA. Такий диференційований ефект HU, летальний для Gфази та інгібіторний для S-фази, може бути корисним для синхронізації асинхронних клітинних популяцій та пояснення терапевтичної дії препарату на людину (Sinclair, 1965).

Наступні дослідження у цьому напрямку ще раз доводять правильність механізму впливу $\mathrm{HU}$ ще на клітинному рівні. На момент дії НU відмічено нормальний ріст клітин у $\mathrm{G}_{1} \mathrm{i}_{2}$ фазах до початку синтезу DNA та настання стану незбалансованого росту i ix відмирання через 8-10 годин (тобто приблизно до початку наступного поділу). На прикладі клітин мишачого фібробласту (L) було показано, що після припинення дії на них $\mathrm{HU}$, або додавання дезоксирибонуклеозиду, відбувається відновлення процесу подвоєння DNA. Як зазначено, порушення синтезу DNA відбувається також через порушення принципу комплементарності у побудові нуклеотидів. У той час як піримідинові деоксирибонуклеозиди легко фосфорилюються клітинами, пуринових нуклеотидів значною мірою перетворюються в рибонуклеотиди.

Повторна інкубація L-клітин протягом 18 годин у $\mathrm{HU}$, показала відновлений синтез DNA, який тривав 
близько 8 годин і залучав 70 \% клітин (Adams \& Lindsay, 1967).

Дослідження противірусної та антимікробної diï $\boldsymbol{H U}$. Ще одним важливим аспектом вивчення HU є дослідження іiі противірусної та антимікробної дії. Тривалий вплив HU на клітини Escherichia coli активізує поглинання ними заліза та токсинів, що призводить до синтезу неповноцінних білків. Такі ефекти змінюють властивості однієї з кінцевих цитохромних оксидаз клітини, викликаючи збільшення синтезу ферменту супероксидази. Синергізм активізованого продукування супероксидаз разом із посиленим засвоєнням заліза сприяє утворенню гідроксильних радикалів, які в кінцевому результаті ведуть до загибелі клітин (Davies et al., 2009).

При вивченні впливу НU встановлено концентрації на розвиток вірусу коров'ячої віспи. У концентрації $5 \cdot 10^{-3} \mathrm{M} \mathrm{HU}$ інгібує утворення інфекційного вірусу на $98,6 \%$, а у концентрації $1 \cdot 10^{-3} \mathrm{M}$ - лише на $75 \%$. Дослідження електронної мікроскопії клітин доводять сповільнений синтез вірусної цитоплазматичної DNA, які витримувались в середовищі з HU. У багатьох 3 них виявлено агрегати недорозвинених вірусних частинок, обмежених одною мембраною, що можна пояснити зупинкою розвитку вірусу на "незрілій” або одномембранній стадії, а також відсутністю у вірусних клітинах сформованих “нуклеоїдів" (Rosenkranz et al., 1966).

Гальмуючи синтез DNA, HU in vitro перешкоджає розмноженню інфекційного бактеріофага Т4. Вона призводить до появи вірусних частинок з деформованими ядрами, які позбавлені DNA. Однак, значна кількість вірусних головок за зовнішнім виглядом були цілком нормальними та, ймовірно, містили DNA (Margaretten et al., 1966).

Дослідження впливу HU на вірус герпесу показало слабку летальну дію, ймовірно через стійку захисну оболонку вірусу - капсид, утворений з білкових молекул. Формування капсиду вірусу герпесу меншої щільності, передує синтезу DNA більшої щільності (Nii et al., 1968).

Досліджено синергетичний ефект HU 3 іншими препаратами. Так, прийом HU для ВІЛ-інфікованих хворих покращувало противірусну активність діданозину (ddI) та ставудину (d4T) протягом 12-тижневого періоду. Спостерігалося незначне збільшення кількості клітин Т-хелперів, що відповідають за імунну реакцію організму. Що ще раз доводить сприяючий ефект HU у появі лімфопенії (Rutschmann et al., 1998). Використання HU може бути альтернативою звичайним методам лікування ВІЛ при використанні іiі разом 3 противірусною терапією. Переваги HU полягають в тому, що вона має добре вивчену побічну дію, зручне дозування, добру переносимість, низьку вартість та унікальний механізм дії (Gibbs \& Sorensen, 2000).

Механізм дї НY у протипухлинній та протираковій mepaniï. Дуже важливими є дослідження механізмів впливу та використання HU у протипухлинній терапії, які проводяться вже більше понад 50 років. За цей час встановлено вплив HU на активність рибонуклеотидної редуктази, яка приймає участь в регуляції синтезу DNA, зокрема, HU блокує вилку реплікації. (Donehower, 1992).

На новому механістичному рівні дослідження розглядають два механізм блокування за допомогою $\mathrm{HU}$ поділу клітини (Singh \& Xu, 2016). Перший полягає у блокуванні вилки реплікації DNA (див. рис. 1 - червоний хрестик), другий - стимулювання антиоксидантного стресу (див. рис. 1 - червоний знак питання). За першим механізмом відбувається пригнічення рибонуклеотидної редуктази (RNR), знижучуючи рівень дезоксирибонуклеотид трифосфату (dNTP) і уповільняння руху DNA-полімераз на вилках реплікації. Уповільнені вилки активують контрольний пункт реплікації DNA. Активована контрольна точка стимулює RNR для збільшення утворення dNTP, необхідних для синтезу DNA для відновлення вилки, та водночас пригнічує мітоз для запобігання аберрантного поділу клітин. Без функціональної контрольної точки уповільнені вилки руйнуються i, таким чином, викликають пошкодження DNA, що веде до загибелі клітин.

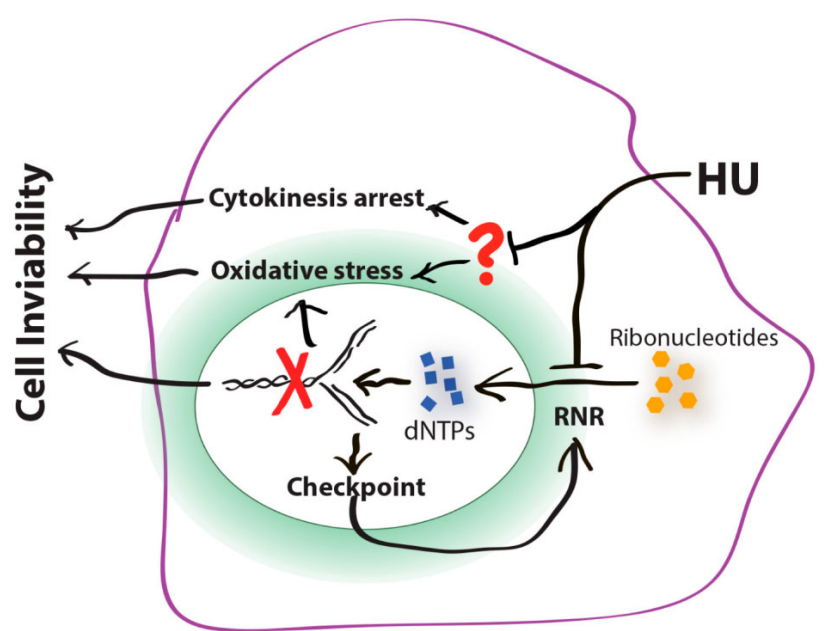

Рис. 1. Механізм блокування поділу клітини гідроксисечовиною HU (Singh \& Xu, 2016)

За другим механізмом відбувається зупинка цитокінезу, спричинена виникненням окислювального стресу, що також призводить до летальності клітин. У цьому видадку HU впливає через іншу мішень, таку як метали ферментів та матричні протеази. Саме завдяки здатності блокувати подвоєння ДНК НU входить до складу важливих протипухлинних ліків.

Хемочутливість до HU ракових клітин легенів людини вивчали in vitro. При концентрації гідроксисечовини $1 \mathrm{mM} \mathrm{в} \mathrm{сироватці} \mathrm{крові} \mathrm{вона} \mathrm{здійснювала} 99 \%$ інгібування росту клітин. Встановлено, що НU можна вводити в дозах до 48 г за 48 год три тижні з незначною токсичністю для тканин і кісткового мозку, а досягнуті рівні in vivo в крові необхідні для ефективного інгібування онкоклітин, як у відповідній моделі in vitro (Veale et al., 1988).

Дослідженнями доведено, що HU інгібує ріст культивованих клітин менінгіоми у мишей, викликаючи апоптоз. HU призначалася при допоміжному хіміотерапевтичному лікуванні пацієнтів 3 рецидивуючими та нерезультативними менінгіомами. Тривале ліку- 
вання HU може призвести до повної ремісії пухлин у пацієнтів із менінгіомою (Schrell et al., 1997). Вона пригнічувала ріст аденокарциноми молочної залози Н2712, особливо коли іï вводили на початковій стадії росту пухлини. Такий ефект спостерігався при щоденній, періодичній або одноразовій ін'єкції та при введенні безпосередньо в пухлину.

Як один 3 найважливіших препаратів, затверджених для лікування серповидноклітинної анемії та хронічних мієлопроліферативних розладів. У дослідженнях було відмічено, що НU підвищує рівень фетального гемоглобіну (HbF) при серповидноклітинній анемії (HbSS), що призводить до зниження частоти вазооклюзивних кризів, зменшуючи необхідність переливання крові пацієнтам. У пацієнтів, які приймають HU, спостерігається значне збільшення нітрозильного гемоглобіну, заліза та нітритів і нітратів у плазмі крові протягом 2 год після прийому, що свідчить про перетворення HU in vivo в оксид азоту (King, 2004).

Вивчено також і механізм виведення препарату із організму. Пероральна абсорбція препарату відбувається повністю, об'єм розподілу еквівалентний вмісту загальної води в організмі, а виведення проходить через ниркові та неренальні механізми. Неренальна елімінація HU характеризується кінетикою МайкласаМентена. Як зазначають (Gwilt et al., 1998), необхідні подальші дослідження фармакокінетики та фармакодинаміки гідроксисечовини: впливу віку та стадії хвороби, взаємозв'язок концентрації та ефекту, роль терапевтичного моніторингу лікарських засобів та механізмів ниркової та неренальної елімінації.

Порівняно недавно удосконаленням відомих методів синтезу для впровадження вітчизняного аналогу оригінального протипухлинного препарату гідреа (ГД) - гідроксикарбамід (НС) проведені у країнах Східної Свропи: Білорусії (Andreeva et al., 2001) та Pociï (Konyaeva et al., 2019). Метою дослідження було вивчення хронічної токсичності препарату ГК (ТОВ “Озон”, Росія) і зареєстрованого препарату порівняння Гідреа (Corden Pharma Latina S. p. А., Італія) на щурах. Показано, що одержані дані хронічної токсичності $є$ дуже близькими і $є$ еквітоксичними за усіма характеристиками.

\section{Матеріал і методи досліджень}

3 початком виявлення цінних фізіологічних властивостей $\mathrm{HU}$ розпочався бурхливий пошук нових та вдосконалення існуючих методів іiі синтезу. Доцільно більш детально дослідити і знайти оптимальні та дешеві методи отримання субстанції з метою розширення асортименту ліків, які блокують подвоєння ДНК і можуть використовуватися для пригнічення росту пухлин.

За хімічною будовою HU можна розглядати як похідне гідроксиламіну $\mathrm{H}_{2} \mathrm{NOH}$ і карбамінової кислоти $\mathrm{H}_{2} \mathrm{NCOOH}$.<smiles>NC(=O)NO</smiles>

Методика (Dresler \& Stein, 1869)

Вперше HU синтезована шляхом взаємодії калію ціанату з сульфатом гідроксиламіну. До охолодженого при $-10{ }^{\circ} \mathrm{C}$ розчину гідроксиламіну сульфату в метанолі, додають порціями водний розчин ціанату калію, в результаті чого утворюється осад сульфату калію $\mathrm{K}_{2} \mathrm{SO}_{4}$, який фільтрують. До фільтрату додають ефip і метанол до утворення однорідної фази. Далі ефірний шар випаровують на водяній бані. 3 розчину при стоянні випадає білий кристалічний осад $\mathrm{HU}$. Утворення НU відбувається за схемою:

$2 \mathrm{KCNO}+\left(\mathrm{NH}_{2} \mathrm{OH}\right)_{2} \cdot \mathrm{H}_{2} \mathrm{SO}_{4} \longrightarrow 2 \mathrm{H}_{2} \mathrm{~N}-\underset{\mathrm{I}}{\mathrm{C}}-\mathrm{N}-\mathrm{OH}+\mathrm{K}_{2} \mathrm{SO}_{4}$

Зазначено, що утворення сечовини як побічного продукту реакції та виділення аміаку, веде до низьких виходів цільового продукту.

Методика (Exner, 1961)

Запропоновано модифікований метод синтезу HU iз сульфату гідроксиламіну і етилкарбамату. За цією методикою до охолодженого при $-5{ }^{\circ} \mathrm{C}$ розчину гідроксиламіну сульфату і калію гідроксиду у воді, додають уретан і залишають на 24 години при кімнатній температурі. Потім реакційну суміш нейтралізують розбавленою сульфатною кислотою до $\mathrm{pH} 6$, охолоджують до $-10{ }^{\circ} \mathrm{C}$ і фільтрують. Розчинник випаровують у вакуумі при $40^{\circ}$ і екстрагують киплячим спиртом HU з виходом $77 \%$ за схемою:

$$
\begin{gathered}
\left(\mathrm{NH}_{2} \mathrm{OH}\right)_{2} \cdot \mathrm{H}_{2} \mathrm{SO}_{4}+2 \mathrm{KOH}+2 \mathrm{H}_{2} \mathrm{NCOOC}_{2} \mathrm{H}_{5} \longrightarrow \\
2 \mathrm{H}_{2} \mathrm{~N}-\underset{\mathrm{C}}{\mathrm{C}}-\mathrm{N}-\mathrm{N}-\mathrm{OH}+\mathrm{K}_{2} \mathrm{SO}_{4}+2 \mathrm{C}_{2} \mathrm{H}_{5} \mathrm{OH} \\
\stackrel{\mathrm{H}}{ }
\end{gathered}
$$

Дещо покращений метод Екснера з використанням натрію етилату замість гідроксиду калію як основи запропонований (Gnilka, 1966). До гарячого розчину натрію етилату додають гідроксиламід гідрохлорид. Реакційну суміш кип'ятять 30 хвилин, потім охолоджують і фільтрують. Фільтрат змішують з твердим уретаном, нагрівають (не вище $50{ }^{\circ} \mathrm{C}$ ) до розчинення осаду i отриману реакційну суміш витримують 72 години при температурі $20^{\circ} \mathrm{C}$. Осад відфільтровують і сушать при температурі $20^{\circ} \mathrm{C}$. Маточний розчин випаровують до половини об'єму і додатково виділяють HU. Вихід за цим методом становить близько $80 \%$.

Методика (Boyland et al., 1966)

3 метою знизити розчинність цільового продукту у воді, почали використовувати неводні розчинники. За цим методом НU одержували в такий спосіб: до охолоджених при $0{ }^{\circ} \mathrm{C}$ розчинів гідрохлориду гідроксиламіну і натрію гідроксиду у воді додають діоксан і через 1,5 години - $\mathrm{COCI}_{2}$ в діоксані. Реакційну суміш залишають на 3 години, потім фільтрують у вакуумі і фракційною кристалізацією з спирту виділяють НU. 


\section{Результати та їх обговорення}

Метою нашою роботи було знайти оптимальні умови синтезу HU з покращеним виходом, ніж описано у літературі. Вище зазначенені методи виявилися трудомісткими та 3 використання токсичних реагентів, таких як калію ціанат, характеризуються невисокими виходами основної речовини внаслідок утворення побічних продуктів реакції. У зв’язку з цим нами запропоновано оптимізувати і покращити умови синтезу HU, що дозволило отримувати препарат 3 більш високим виходом (до $91 \%$ ) та досягнуто простоту і одностадійність методу.

Експериментальна частина. 85,0 г (0,62 мол) КОН розчиняють в 100 мл води і охолоджують до $0{ }^{\circ} \mathrm{C}$. До отриманого розчину додають порціями охолоджений розчин 102,0 г (0,62 мол) сульфату гідроксиламіну в 200 мл води при постійному перемішуванні реакційної суміші і охолодженні іiі до $0{ }^{\circ} \mathrm{C}$. Відфільтровують твердий осад $\mathrm{K}_{2} \mathrm{SO}_{4}$, до фільтрату при постійному перемешуванні протягом 15 хвилин додають 89,0 г (1,0 мол) уретану і залишають на 24 години. Потім проводять нейтралізацію 50 \% сірчаною кислотою до $\mathrm{pH} 6$, витримуючи температуру реакційної суміші при $-15^{\circ} \mathrm{C}$, і залишають при перемішуванні ще на 30 хвилин. Осад відфільтровують і висушують на повітрі. 3 фільтрату добувають ще додаткову кількість НU. Обидва осади об'єднують і екстрагують 4 рази по 250 мл бутанолу, з якого при охолодженні і випаровуванні розчинника кристалізується продукт у вигляді крижаних пластинок. За зовнішнім виглядом білий кристалічний порошок, добре розчинний у воді, метанолі, розчинний при кип'ятінні в діоксані і не розчинний в бензолі і хлороформі Т. пл. 135-136 ${ }^{\circ} \mathrm{C}(128-$ $130{ }^{\circ} \mathrm{C}$ у Exner, 1961); Знайдено, \%: C, 15.80, 15,78; Н, 5.25, 5.32; N, 36.86, 36.89. $\mathrm{CH}_{4} \mathrm{~N}_{2} \mathrm{O}_{2}$. Вирахувано, \%: C, 15.79; H, 5.30; N, 36.84 .

Таким чином, до модифікованих та оптимізованих умов синтезу можна віднести проведення експерименту при нижчих температурах $-15{ }^{\circ} \mathrm{C}\left(-10{ }^{\circ} \mathrm{C}\right.$ літ.), нейтралізація реакційної суміші концентрованою $50 \%$ сірчаною кислотою (а не розбавленою, літ.); забезпечення концентрованих умов за рахунок зменшення загальної кількості води в реакції 300 мл (500 мл, літ.); випаровуванням фільтрату при кімнатній температурі потоком повітря (випаровування в вакуумі при $40{ }^{\circ} \mathrm{C}$, літ); заміна розчинника для екстракцієї на бутанол (спирт, літ.). Такі умови забезпечили повне розчинення уретану вже через 1 год і дозволяють отримати цільовий продукт у чистому вигляді, який практично не вимагає перекристалізації.

\section{Висновки}

Опрацьовано літературні джерела щодо шляхів та механізмів дії HU в живих організмах, дослідження противірусної та антимікробної дії $\mathrm{HU}$, механізму впливу HU на клітинному рівні та у протипухлинній та протираковій терапії. Завдяки тому, що HU має здатність пригнічувати поділ клітин за рахунок блокування вилки реплікації DNA, цей препарат викори- стовується як антинеопластичний засіб в гематології та для лікування онкологічних захворювань.

Для отримання достатньої кількості препарату для наукових досліджень було покращено оптимальні умови синтезу HU, що забезпечило одержання цільового продукту з вищим виходом (до 91 \%) та досягнуто простоту і одностадійність методу. Також з метою здешевити процес синтезу були використані менш токсичні та економічно вигідні вихідні реагенти.

\section{References}

Andreeva, T. N., Grygorev Yu. V., \& Kalyshuk, D.G (2001). Razrabotka malootxodnoj texnologyy poluchenyya farmakopejnoj N-gydroksymochevyny. My`nsk: BGTU, 34-35 (in Russian).

Bezlepkyn, V. H., Malynovs'kyy, YU. YU., \& Haziyev, A. I. (1985) Indukovanyy radiatsiyeyu pozaplanovyy syntez DNK i DNK-polimeraznoyi aktyvnist' na yadernomu matryksi. Biopolimery i klityna, 1(5), 259-265 (Russian).

Adams, R. L., \& Lindsay, J. G. (1967). Hydroxyurea reversal of inhibition and use as a cell-synchronizing agent. J Biol Chem., 242(6), 1314-1317. URL: https://pubmed.ncbi.nlm.nih.gov/6023572.

Boyland, E., \& Nero, R. (1966). The synthesis and some reactions of dihydroxyurea. J. Chem. Soc, 3, 350-353.

Davies, B. W., Kohanski, M. A., Simmons, L. A., Winkler, J. A., Collins, J. J., \& Walker, G. C. (2009). Hydroxyurea induces hydroxyl radical-mediated cell death in Escherichia coli. Molecular cell, 36(5), 845860. doi: 10.1016/j.molcel.2009.11.024

Donehower, R. C. (1992). An overview of the clinical experience with hydroxyurea. Seminars in Oncology, 19(3 Suppl 9), 11-19. URL: https://pubmed.ncbi.nlm.nih.gov/ 1641651.

Dresler, W. F. C., \& Stein, R. (1869). Uber der Hydroxylarnstoff. Ann., 150, 242.

Gibbs, M. A., \& Sorensen, S. J. (2000). Hydroxyurea in the treatment of HIV-1. Annals of Pharmacotherapy, 34(1), 89-93. doi: 10.1345/aph.19004.

Gnilka, J. (1966). Sposob wytwarzania hydroxymocznica. Lodzkie Zaklady Farmaceutyczne "Polfa". Pat. PNR, pl. 120, 17/03, (SO7s) № 51704, zaiavl. 30.02.64, opubl. 30.07.66, RZhKh 1968: 19N3KP (in Russian).

Gwilt, P. R., \& Tracewell, W. G. (1998). Pharmacokinetics and Pharmacodynamics of Hydroxyurea. Clin Pharmacokinet, 34, 347-358. doi: 10.2165/00003088-199834050-00002.

Exner, O. (1961) Über die Acylderivate des Hydroxylamins VI. Zur Konstitution von Hydroxybiuret und Hydroxydiphenylbiuret. Collect Czehosl. Chem. Communs, 26(3), 701-709. URL: http://cccc.uochb.cas.cz/26/3/0701.

King, S. B. (2004). Nitric oxide production from hydroxyurea. Free Radical Biology and Medicine, 37(6), 737-744. doi: 10.1016/j.freeradbiomed.2004.02.073.

Konyaeva, O. I., Kulbachevskaya, N. Yu, Chaley, V. A., Ermakova, N. P., Merkulova, I. B., Abramova, T. V., \& Kasatkina, I. S. (2019). Equitoxicity of domestic hydroxycarbamide and reference drug Hydrea in rats. 
Russ. J. Biother, 18(1), 80-86. doi: 10.17650/17269784-2019-18-1-80-86 (in Russian).

Lanzkron, S., Strouse, J. J., Wilson, R., Beach, M. C., Haywood, C., Park, H., Witkop, C., Eric, E. B., \& Segal, J. B. (2008). Systematic Review: Hydroxyurea for the Treatment of Adults with Sickle Cell Disease. Ann. Intern. Med, 148(12), 939-955. URL: https://www.ncbi.nlm.nih.gov/pmc/articles/PMC3256 736.

Margaretten, W., Morgan, C., Rosenkranz, H. S., \& Rose, H. M. (1966). Effect of Hydroxyurea on Virus Development I. Electron Microscopic Study of the Effect on the Development of Bacteriophage T4. Journal of bacteriology, 91(2), 823-833. URL: https://www.ncbi.nlm. nih.gov/pmc/articles/PMC314936.

Nii, S., Rosenkranz, H. S., Morgan, C., \& Rose, H. M. (1968). Electron microscopy of herpes simplex virus III. Effect of hydroxyurea. Journal of virology, 2(10), 1163-1171. URL: https://www.ncbi.nlm.nih.gov/pmc/ articles/PMC375449.

Rosenkranz, H. S., Rose, H. M., Morgan, C., \& Hsu, K. C. (1966). The effect of hydroxyurea on virus development: II. Vaccinia virus. Virology, 28(4), 510-519. doi: 10.1016/0042-6822(66)90235-2.

Rutschmann, O. T., Opravil, M., Iten, A., Malinverni, R., Vernazza, P. L., Bucher, H. C., \& Perrin, L. H. (1998). A placebo-controlled trial of didanosine plus stavudine, with and without hydroxyurea, for HIV infection. Aids, 12(8), 71-77. doi: 10.1097/00002030199808000-00003.

Saban, N., \& Bujak M. (2009). Hydroxyurea and hydroxamic acid derivatives as antitumor drugs.
Cancer Chemother Pharmacol, 64, 213-221. doi: 10.1007/s00280-009-0991-z.

Sinclair, W. K. (1965). Hydroxyurea: differential lethal effects on cultured mammalian cells during the cell cycle. Science, 150(3704), 1729-1731. doi: 10.1126/science.150.3704.1729.

Singh, A., \& Xu, Y. J. (2016). The Cell Killing Mechanisms of Hydroxyurea. Genes (Basel), 7(11), 99. doi: 10.3390/genes7110099.

Schrell, U. M., Rittig, M. G., Anders, M., Kiesewetter, F., Marschalek, R., Koch, U. H., \& Fahlbusch, R. (1997). Hydroxyurea for treatment of unresectable and recurrent meningiomas. I. Inhibition of primary human meningioma cells in culture and in meningioma transplants by induction of the apoptotic pathway. Journal of neurosurgery, 86(5), 845-852. doi: 10.3171/jns. 1997.86.5.0840.

Souza, S. S., dos Santosa, I. G., da Silvaa, C. V., \& Laignier Cazedey, E. C. (2020). Qualitative Analysis of Hydroxyurea. Drug Anal. Res., 4(1), 18-21. doi: 10.22456/2527-2616.100682.

Timson, J. (1975). Hydroxyurea. Mutation Res. 32, 115132.

Veale, D., Cantwell, B. M. J., Kerr, N., Upfold, A., \& Harris, A. L. (1988). Phase 1 study of high-dose hydroxyurea in lung cancer. Cancer Chemother Pharmacol, 21(1), 53-56. doi: 10.1007/BF00262739.

Wilson, J. G., Scott, W. J., Ritter, E. J., \& Fradkin, R. (1975). Comparative distribution and embryotoxicity of hydroxyurea in pregnant rats and rhesus monkeys. Teratology, 11(2), 169-178. doi: 10.1002/ tera. 1420110205 . 